\title{
Methane Emissions among Hybrid Rice Cultivars in the Mid- Southern United States
}

\author{
A.D. Smartt ${ }^{1}$, K.R. Brye ${ }^{1}$, R.J. Norman ${ }^{1}$ \\ ${ }^{1}$ Department of Crop, Soil, and Environmental Sciences, University of Arkansas, Fayetteville, USA \\ Email: adsmartt@uark.edu
}

\begin{abstract}
Rice (Oryza sativa L.) production systems have a greater global warming potential than upland row crops due to methane $\left(\mathrm{CH}_{4}\right)$ emissions resulting from anaerobic conditions associated with flood-irrigated soils. Based on recent research indicating the potential for hybrid cultivars to mitigate $\mathrm{CH}_{4}$ emissions from rice, the objective of this study was to determine the influence of several commonly grown hybrid rice cultivars on $\mathrm{CH}_{4}$ fluxes and emissions from a silt-loam soil. Four cultivars were evaluated: the three hybrids CLXL729, CLXL745, and XL753 and the pure-line cultivar Roy J. Methane fluxes were determined by measuring changes in headspace $\mathrm{CH}_{4}$ concentrations over a period of 1 hour using 30-cm-inner-diameter polyvinyl chloride chambers. Only minor differences in $\mathrm{CH}_{4}$ fluxes occurred among the three hybrid cultivars, while the pure-line cultivar (Roy J) generally had greater $(P<0.05)$ fluxes. Peak $\mathrm{CH}_{4}$ fluxes occurred just after heading and were greater $(P<0.05)$ from Roy $\mathrm{J}\left(7.9 \mathrm{mg} \mathrm{CH}_{4}-\mathrm{C} \mathrm{m}^{-2} \mathrm{~h}^{-1}\right)$ than from the three hybrid cultivars, which did not differ and averaged $5.1 \mathrm{mg} \mathrm{CH}_{4}-\mathrm{C} \mathrm{m}^{-2} \mathrm{~h}^{-1}$. Seasonal $\mathrm{CH}_{4}$ emissions were greater $(P<$ 0.05) from Roy $\mathrm{J}\left(74.8 \mathrm{~kg} \mathrm{CH}_{4}-\mathrm{C} \mathrm{ha}^{-1}\right.$ season $^{-1}$ ) than from CLXL729, XL753, and CLXL745, which did not differ, and averaged 55.3, 53.0, and $48.9 \mathrm{~kg} \mathrm{CH}_{4}-\mathrm{C}$ ha-1 season $^{-1}$, respectively. Results of this study indicate the use of common hybrid cultivars may have potential for mitigation of $\mathrm{CH}_{4}$ emissions from rice production on silt-loam soils in the mid-southern United States.
\end{abstract}

Keywords: Methane emissions, rice cultivar, hybrid rice, methane mitigation

\section{$1 \quad$ Introduction}

Rice (Oryza sativa L.) is the world's only major row crop that substantially contributes to global methane $\left(\mathrm{CH}_{4}\right)$ emissions. While most crops are grown under aerated soil conditions and act as net sinks for atmospheric $\mathrm{CH}_{4}$, the majority of rice throughout the globe is produced in flooded fields [1] and acts as a net source of $\mathrm{CH}_{4}$ into the atmosphere. The anoxic conditions resulting from flooded soils lead to the production and release of $\mathrm{CH}_{4}$, a greenhouse gas with a global warming potential (GWP) 25 times stronger than carbon dioxide $\left(\mathrm{CO}_{2}\right)$ [2]. Due to the production of $\mathrm{CH}_{4}$, rice cultivation has been estimated to have a GWP 2.7 and 5.7 times stronger than the production of maize (Zea mays L.) and wheat (Triticum aestivum L.), respectively, with $90 \%$ of the GWP of rice systems attributed to $\mathrm{CH}_{4}[3$, 4]. It has been estimated, on a global scale, that approximately half of all anthropogenic $\mathrm{CH}_{4}$ emissions to the atmosphere are a direct result of agricultural activities $[5,6]$ and that $22 \%$ of those agricultural $\mathrm{CH}_{4}$ emissions occur due to rice cultivation [7]. Arkansas is the leading rice-producing state in the US, representing over $49 \%$ of harvested area in 2014 and resulting in an estimated $39 \%$ of total $\mathrm{CH}_{4}$ emissions from rice cultivation in the US in 2014 [8].

Methane emissions from a rice cultivation system are governed by the magnitude and balance between the two microbial processes of methanogenesis, the production of $\mathrm{CH}_{4}$, and methanotrophy, the oxidation of $\mathrm{CH}_{4}$, both of which are strongly influenced by various soil, plant, and environmental factors. Methanogenesis occurs in anaerobic soils as a specific group of Archaea utilize acetate or hydrogen gas and $\mathrm{CO}_{2}$, which are formed by the fermentation of organic matter by a large consortium of anaerobic bacteria, as substrates to form $\mathrm{CH}_{4}[9,10]$. A specific group of methanogens referred to as Rice Cluster I was identified by Grosskopf et al. [11] and was determined to represent up to $50 \%$ of methanogens in rice systems [12], occupying a niche surrounding rice roots by producing $\mathrm{CH}_{4}$ from root exudates released into the soil $[13,14]$. Methane oxidation in flooded-rice systems occurs at oxic-anoxic interfaces where a group of aerobic Proteobacteria, known as methanotrophs, utilize $\mathrm{CH}_{4}$ or methanol as a source 
of energy and carbon [9]. Research has consistently indicated that up to $90 \%$ of $\mathrm{CH}_{4}$ produced in rice cultivation systems is oxidized by methanotrophs $[15,16,17,18,19]$ as $\mathrm{CH}_{4}$ moves through the oxygenated zones of soil surrounding rice roots [20, 21] and near the soil surface [19, 22].

$\mathrm{A} \mathrm{CH}_{4}$ mitigation strategy that has been recently investigated is the selection of specific rice cultivars that could potentially reduce $\mathrm{CH}_{4}$ emissions. While the implementation of certain mitigation options by producers may be restricted due to required changes in management practices and equipment or the possibility of yield reductions, the selection of low-emitting cultivars can be implemented without major changes in crop management while maintaining grain yields. Studies have indicated that about $90 \%$ of $\mathrm{CH}_{4}$ emissions from rice fields occur by plant-mediated transport through the aerenchyma tissues of rice plants $[16,19,23,24]$. Due to the strong influence of rice plants themselves on $\mathrm{CH}_{4}$ emissions from the system, innate physiological differences between cultivars may lead to differences in $\mathrm{CH}_{4}$ transport capacities [23], differences in biomass accumulation [25] and root exudation [26, 27, 28], or differences in microbial populations in the rhizpsphere [29]. Many studies throughout rice-growing countries have reported differences in $\mathrm{CH}_{4}$ emissions among rice cultivars; however, the complexity of the system and processes involved have led to differing results and, at this point, no single parameter has been identified to consistently explain differences in $\mathrm{CH}_{4}$ emissions among cultivars. Due to the wide variety of environmental conditions, production practices, and rice cultivars that occur throughout the world, it seems that $\mathrm{CH}_{4}$ emissions measurements need to be conducted to account for the specific production practices and cultivars that predominate in each rice-growing region in order to mitigate $\mathrm{CH}_{4}$ emissions while maintaining high yields and profitability.

Research has recently been conducted to evaluate rice cultivar effects on $\mathrm{CH}_{4}$ emissions in the US with studies occurring in California and Arkansas. The studies conducted in Arkansas observed reductions in $\mathrm{CH}_{4}$ emissions ranging from 25 to $37 \%$ from a japonica/indica hybrid cultivar relative to pure-line conventional cultivars [30, 31, 32], while Simmonds et al. [31] measured no difference in $\mathrm{CH}_{4}$ emissions from the same hybrid cultivar (CLXL745) and pure-line cultivars in California. Although limited data have been collected in the US, cultivar selection has been shown to significantly impact $\mathrm{CH}_{4}$ emissions from rice. An examination of the mitigation potential of hybrid rice cultivars is important in Arkansas, where over $40 \%$ of rice area has been planted with hybrid cultivars since 2008 [33]. Previous studies have observed reduced emissions from the hybrid cultivar CLXL745 in Arkansas; however, no studies have been conducted to investigate if the reduced emissions are consistent with other hybrid rice cultivars. This study focused on comparing a single pure-line cultivar to several hybrid cultivars to investigate if other hybrids showed similar $\mathrm{CH}_{4}$ mitigation potential as was observed from CLXL745. This study adds significant data from drill-seeded, delayed-flood rice production systems in the mid-southern US concerning cultivar effects on $\mathrm{CH}_{4}$ emissions that will be instrumental in estimating current $\mathrm{CH}_{4}$ emissions as well as mitigating potential future emissions. Thus, the objective of this study was to evaluate hybrid rice cultivar effects on $\mathrm{CH}_{4}$ emissions from a silt-loam soil during the 2014 growing season. It was hypothesized that $\mathrm{CH}_{4}$ fluxes and emissions would not differ among hybrid cultivars, but that all hybrid cultivars collectively would produce lower mean emissions compared to a pure-line cultivar.

\section{Materials and Methods}

\subsection{Site Description}

Research was conducted during the 2014 growing season, from May to September, at the University of Arkansas System Division of Agriculture Rice Research and Extension Center near Stuttgart in

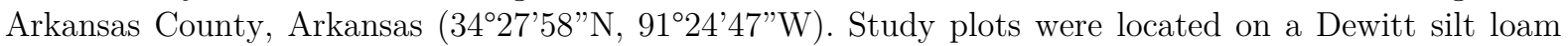
(fine, smectitic, thermic Typic Albaqualfs) [34]. The study site is located in the northern portion of the Southern Mississippi River Terraces Major Land Resource Area (MLRA 131D) known as the Grand Prairie in east-central Arkansas. Cropland makes up approximately $42 \%$ of MLRA 131D, where precipitation, which mostly occurs in the spring and early summer, averages between 124.5 and $142 \mathrm{~cm}$ annually and the annual average air temperature ranges from 16 to $18{ }^{\circ} \mathrm{C}$ [35]. The crops at this study location have been rotated annually between soybean and rice for more than 20 years and previous crop residues are incorporated into the top 10 to $15 \mathrm{~cm}$ of soil between growing seasons. 


\subsection{Treatments and Experimental Design}

The purpose of this study was to determine if other hybrid rice cultivars produced similar $\mathrm{CH}_{4}$ emissions results to the hybrid cultivar CLXL745, which has been previously studied. Cultivars were selected in this study in an attempt to represent the most common hybrid cultivars as well as a comparison to one of the most predominant pure-line cultivars currently grown in Arkansas. The three hybrid rice cultivars selected for this study were "CLXL745", "XL753", and "CLXL729" (RiceTec, Inc., Houston, TX), which accounted for 22.0, 11.8, and 4.2\%, respectively, of Arkansas rice production in 2014 and 21.3, 13.6, and $4.1 \%$, respectively in 2016 [36]. The final selection in this study was the pure-line cultivar "Roy J", developed at the University of Arkansas [37], which accounted for 12.6\% of Arkansas production in 2014 and $19.6 \%$ in 2016 [36]. All four cultivars produce long-grain rice, and, while the pure-line cultivar, Roy $\mathrm{J}$, is a mid-season cultivar, heading at 85 days after emergence, the hybrid cultivars CLXL745, XL753, and CLXL729 are all short-season cultivars, heading at 77, 78, and 80 days after emergence, respectively [38]. All four rice cultivars are high yielding with CLXL729, CLXL745, XL753, and Roy J averaging 9.9, 10.0, 12.7, and 9.9 $\mathrm{Mg} \mathrm{ha}^{-1}$, respectively, in Arkansas Rice Performance Trials in 2014 [38].

Research plots, which were arranged in a randomized complete block (RCB) design with four replicates of each cultivar, were $1.6 \mathrm{~m}$ wide by $5 \mathrm{~m}$ long and encompassed nine rows of rice. Methane sample date was treated as a repeated measure in analyzing $\mathrm{CH}_{4}$ flux data.

\subsection{Plot Management}

Study plots were managed in accordance with University of Arkansas Cooperative Extension Service (UACES) guidelines [39]. As per soil test recommendations, $100 \mathrm{~kg} \mathrm{ha}^{-1}$ each of phosphorus $(\mathrm{P})$ and potassium (K) and $11.2 \mathrm{~kg} \mathrm{ha}^{-1}$ of Zn were incorporated by tillage into the top 10 to $15 \mathrm{~cm}$ of soil on 26 March 2014 throughout the study area. Research plots were then independently drill-seeded, using 18cm row spacing, on 5 May 2014. The pure-line cultivar, Roy J, was seeded at a rate of $82 \mathrm{~kg} \mathrm{ha}^{-1}$, while all three hybrid cultivars were seeded at a lower rate of $34 \mathrm{~kg} \mathrm{ha}^{-1}$ due to an increased tillering capacity in hybrid rice cultivars. Levees were constructed to surround the study area following seeding and plots were flush-irrigated with nearby reservoir water as necessary prior to the establishment of a permanent flood, which occurred on 17 June 2014 when rice was at the 4- to 5-leaf stage. Based on UACES guidelines, $\mathrm{N}$ was applied as urea $(46 \% \mathrm{~N})$ in a split application, where Roy J and CLXL729 each received $100 \mathrm{~kg} \mathrm{~N}$ ha-1 and CLXL745 and XL753 each received $135 \mathrm{~kg} \mathrm{~N}^{-1}{ }^{-1}$ as the first split one day prior to permanent flood establishment [40]. The second split application of $\mathrm{N}$ occurred on 10 July 2014 at the beginning of internode elongation for Roy $\mathrm{J}\left(50 \mathrm{~kg} \mathrm{~N} \mathrm{ha}^{-1}\right)$ and at the booting growth stage on 23 July 2014 for the three hybrid cultivars $\left(33 \mathrm{~kg} \mathrm{~N} \mathrm{ha}^{-1}\right)$. A floodwater depth of 5 to $10 \mathrm{~cm}$ was maintained by use of Polytube (Delta Plastics, Little Rock, AR) inlet irrigation until grain maturity was reached on 3 September 2014, upon which floodwater was released and plots were allowed to dry for harvest, which occurred on 18 September 2014 with a small-plot combine. Plots were regularly scouted and managed to remain below threshold levels of insects and weeds throughout the season according to UACES guidelines [41, 42].

\subsection{Soil Sampling}

Soil samples were collected prior to $\mathrm{N}$ fertilization and flooding using a 2-cm-diameter push probe by combining five cores from the 0 - to 10 -cm depth in each plot. Composite samples were dried at $70{ }^{\circ} \mathrm{C}$ for $48 \mathrm{~h}$ and sieved through a 2-mm mesh screen prior to subsamples being analyzed for Mehlich-3 extractable nutrients (i.e., $\mathrm{P}, \mathrm{K}, \mathrm{Ca}, \mathrm{Mg}, \mathrm{Fe}, \mathrm{Mn}, \mathrm{Na}, \mathrm{S}, \mathrm{Cu}$, and $\mathrm{Zn}$; Spectro Analytical Instruments, Spectro Arcos ICP, Kleve, Germany) using inductively coupled plasma atomic emission spectroscopy [43]. Total N (TN) and total C (TC) concentration were determined from additional subsamples by high-temperature combustion using a VarioMax CN analyzer (Elementar Americas Inc., Mt. Laurel, NJ) [44]. Soil pH and electrical conductivity (EC) were determined potentiometrically on a 1:2 (m:v) soil-tosolution paste. Soil organic matter $(\mathrm{OM})$ concentration was determined by loss on ignition [45]. Bulk density samples were collected from the 0 - to $10-\mathrm{cm}$ depth using a slide hammer and 4.7-cm-diameter core chamber with a beveled core tip, dried at $70{ }^{\circ} \mathrm{C}$ for $48 \mathrm{~h}$, weighed and ground to pass through a 2$\mathrm{mm}$ mesh screen for particle-size analysis using a modified 12-h hydrometer method [46]. Measurements 
of bulk densities from the plots were used in conjunction with measured TN, TC, and OM concentrations to determine TN, TC, and SOM contents $\left(\mathrm{Mg} \mathrm{ha}^{-1}\right)$.

\subsection{Gas Sampling and Analysis}

Enclosed headspace chambers, as detailed by Livingston and Hutchinson [47] and similar to those used in previous studies [30, 32, 48, 49], were used for collection of gas samples. This methodology is commonly used for measuring trace gas fluxes [50] and involves the use of 30-cm inner diameter (ID) polyvinyl chloride to create a permanent base collar, several sizes of chamber extensions to accommodate increasing plant growth over time, and a vented sampling cap to sample a portion of each plot. One base collar, which remained in the same place throughout the study, was placed within each plot to contain $40 \mathrm{~cm}$ of rice row length in order to duplicate the plant density of the plots. Elevated boardwalks were established at the perimeter of plots prior to flooding in order to access chambers during sampling, while minimizing disturbance of plants and soil surrounding the chambers. Chamber caps contained a $15-\mathrm{cm}$ section of $4.5-\mathrm{mm}$ ID copper tubing as a vent to maintain atmospheric pressure, gas sampling and thermometer ports sealed with gray butyl-rubber septa (Voight Global, part number 73828A-RB, Lawrence, KS), and a 2.5-cm-diameter, 9V-battery-operated fan (Sunon Inc, MagLev, Brea, CA) to mix the headspace air within the chamber during sampling.

Gas sampling throughout the study occurred between 0800 and 1000 hours, similar to previous studies $[30,32,48,49,51,52,53]$, in order to prevent excessive heating within the chambers during sampling. Gas samples for flux measurements occurred on approximately weekly intervals at 7, 14, 21, 28, 35, 43, 49, 56, 63, 71, and 77 days after flooding (DAF) for the flooded duration of the study. Sampling intensity was increased after flood release to 80, 82, 83, 84, and 85 DAF [i.e., 2, 4, 5, 6, and 7 days after flood release (DAFR)] in an attempt to adequately quantify a post-flood-release pulse of $\mathrm{CH}_{4}$ that has commonly been observed in previous studies [32, 48, 49, 51, 54, 55, 56].

On each sampling date, samples were collected at 20-minute intervals (i.e., 0, 20, 40, and 60 minutes after cap closure) using 20-mL B-D syringes (Becton Dickinson and Co., Franklin Lakes, NJ) and immediately transferred into evacuated 10-mL, crimp-top glass vials (Agilent Technologies, part number 5182-0838, Santa Clara, CA). Field samples were analyzed within 48 hours using an Agilent 6890-N gas chromatograph equipped with a flame ionization detector (FID). Methane fluxes were then calculated based on changes of headspace $\mathrm{CH}_{4}$ concentrations over time as outlined by Parkin and Venterea [50]. Season-long total $\mathrm{CH}_{4}$ emissions were determined for each chamber by linear interpolation between flux measurement dates. More detailed descriptions of gas sampling and analysis procedures used in this study have been previously reported $[32,49]$.

\subsection{Plant Sampling and Analyses}

Plant samples were collected on 17 September 2014, one day prior to harvest, in order to determine any impact of rice cultivar on total aboveground dry matter accumulation over the growing season as well as to compare aboveground dry matter from within and outside the chambers to determine if the chambers had a negative impact on plant growth. All aboveground biomass from within each chamber and a 1-m row of rice from adjacent to each chamber were cut, dried at $60^{\circ} \mathrm{C}$ until no further moisture loss occurred, and weighed in order to determine total aboveground dry matter accumulation. A 4-m length of the center five rows of each plot was harvested at physiological maturity using a plot-scale combine. Grain samples were then weighed and analyzed for moisture content so that final grain yields could be reported on a $120 \mathrm{~g} \mathrm{~kg}^{-1}$ grain moisture content.

\subsection{Statistical Analyses}

Initial soil physical and chemical properties were analyzed by analysis of variance (ANOVA) in SAS v. 9.4 (SAS Institute, Inc., Cary, NC) using PROC Mixed based on a RCB design in order to evaluate whether inherent differences were present in soil properties among plots planted to each cultivar. Similarly, grain yield was analyzed by ANOVA based on a RCB design in order to determine the impact of rice cultivar on grain yield. An additional ANOVA was performed based on a split-plot RCB design, where cultivar was the whole-plot factor and sampling location (i.e., in-chamber or in-plot) was the 
split-plot factor, in order to compare total aboveground dry matter accumulation as affected by cultivar and sampling location.

Methane flux data showed no indication of non-normal distribution based on a visual inspection for normality using normal probability plots of the studentized residuals. Therefore, an ANOVA was performed based on a RCB repeated-measures design, where sampling event was treated as a repeated measure, in order to evaluate cultivar impact on $\mathrm{CH}_{4}$ fluxes over time. Flux data were analyzed separately for the flooded and non-flooded periods of the season due to differences in $\mathrm{CH}_{4}$ transport mechanisms and sampling frequency. Total seasonal $\mathrm{CH}_{4}$ emissions effects among cultivars, expressed as mass-per-area (area scaled) and mass-per-grain-yield (yield scaled), as well as post-flood-release emissions, on an area-scaled basis and as a percentage of total seasonal emissions, were analyzed by ANOVA based on a RCB design. When appropriate, means were separated at the 0.05 level using the Fisher protected least significant difference (LSD).

\section{$3 \quad$ Results and Discussion}

\subsection{Initial Soil Properties}

Table 1. Mean soil physical and chemical properties $(\mathrm{n}=4$ per cultivar) prior to flood establishment in the top 10 $\mathrm{cm}$ of a Dewitt silt loam during the 2014 growing season at the Rice Research and Extension Center near Stuttgart, $\mathrm{AR}$.

\begin{tabular}{lcccc}
\hline \multicolumn{5}{c}{ Cultivar } \\
\hline Soil property & CLXL729 & CLXL745 & XL753 & Roy J \\
\hline $\mathrm{pH}$ & 6.44 & 6.49 & 6.45 & 6.42 \\
\hline Sand $\left(\mathrm{g} \mathrm{g}^{-1}\right)$ & 0.07 & 0.07 & 0.08 & 0.07 \\
\hline Silt $\left(\mathrm{g} \mathrm{g}^{-1}\right)$ & 0.75 & 0.76 & 0.76 & 0.76 \\
\hline Clay $\left(\mathrm{g} \mathrm{g}^{-1}\right)$ & 0.17 & 0.17 & 0.17 & 0.17 \\
\hline Bulk density $\left(\mathrm{g} \mathrm{cm}^{-3}\right)$ & 1.34 & 1.35 & 1.34 & 1.34 \\
\hline Electrical conductivity $\left(\mathrm{dS} \mathrm{m} \mathrm{m}^{-1}\right)$ & 0.216 & 0.193 & 0.191 & 0.205 \\
\hline Mehich-3 extractable nutrients $\left(\mathrm{mg} \mathrm{kg}^{-1}\right)$ & & & \\
\hline $\mathrm{P}$ & 44.9 & 50.0 & 43.6 & 52.4 \\
\hline $\mathrm{K}$ & 136 & 139 & 133 & 148 \\
\hline $\mathrm{Ca}$ & 1645 & 1644 & 1636 & 1666 \\
\hline $\mathrm{Mg}$ & 158 & 158 & 156 & 159 \\
\hline $\mathrm{Fe}$ & 363 & 365 & 361 & 367 \\
\hline $\mathrm{Mn}$ & $249 \mathrm{ab}$ & $240 \mathrm{c}$ & $246 \mathrm{abc}$ & $251 \mathrm{a}$ \\
\hline $\mathrm{Na}$ & $56.4 \mathrm{a}$ & $52.9 \mathrm{bc}$ & $51.6 \mathrm{c}$ & $55.6 \mathrm{ab}$ \\
\hline $\mathrm{S}$ & 12.5 & 11.3 & 11.5 & 13.5 \\
\hline $\mathrm{Cu}$ & 1.32 & 1.31 & 1.30 & 1.32 \\
\hline $\mathrm{Zn}$ & 5.08 & 5.05 & 3.75 & 5.19 \\
\hline Organic matter $\left(\mathrm{g} \mathrm{kg}^{-1}\right)$ & 19.6 & 19.9 & 20.1 & 20.2 \\
\hline Organic matter $\left(\mathrm{Mg} \mathrm{ha}^{-1}\right)$ & 26.2 & 27.0 & 26.9 & 27.0 \\
\hline Total N $\left(\mathrm{g} \mathrm{kg}^{-1}\right)$ & 0.88 & 0.90 & 0.88 & 0.91 \\
\hline Total N $\left(\mathrm{Mg} \mathrm{ha}^{-1}\right)$ & 1.17 & 1.22 & 1.17 & 1.21 \\
\hline Total C $\left(\mathrm{g} \mathrm{kg}^{-1}\right)$ & 9.1 & 8.8 & 8.9 & 8.7 \\
\hline Total C $\left(\mathrm{Mg} \mathrm{ha}^{-1}\right)$ & 12.2 & 11.9 & 11.9 & 11.6 \\
\hline C:N ratio & 10.4 & 9.8 & 10.2 & 9.6 \\
\hline & & & & \\
\hline
\end{tabular}

${ }^{\dagger}$ Values in the same row followed by different letters are significantly different $(P<0.05)$.

Initial soil physical and chemical properties in the top $10 \mathrm{~cm}$ measured prior to flooding did not differ among pre-assigned treatments (Table 1), with the exception of extractable $\mathrm{Na}(P=0.035)$ and 
extractable $\mathrm{Mn}(P=0.004)$. However, the magnitude of differences among pre-assigned treatments amounted to 8.9 , and $4.5 \%$ of the overall mean values among all four cultivars for extractable soil $\mathrm{Na}$ and $\mathrm{Mn}$, respectively (Table 1). These minor differences in the properties of soil upon which each treatment was implemented likely had no practical or agronomic significance in this study. Extractable

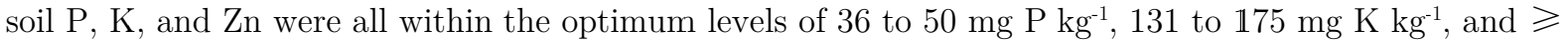
$4.1 \mathrm{mg} \mathrm{Zn} \mathrm{kg}{ }^{-1}$ recommended for optimal rice produced on a silt-loam soil, indicating adequate levels of these nutrients for production of optimum rice yields based on UACES guidelines [40].

\subsection{Methane Fluxes from Flooding to Flood Release}

Table 2. Analysis of variance summary of the effects of cultivar, time, and their interaction on methane $(\mathrm{CH} 4)$ fluxes from flooding to flood release and following flood release from a silt-loam soil during the 2014 growing season at the Rice Research and Extension Center near Stuttgart, AR.

\begin{tabular}{|c|c|c|}
\hline \multirow[b]{2}{*}{ Source of variation } & \multicolumn{2}{|c|}{ Measurement period } \\
\hline & Flooding to flood release & Post-flood release \\
\hline & \multicolumn{2}{|c|}{------------- P ------------- } \\
\hline Cultivar & 0.002 & 0.042 \\
\hline Time & $<0.001$ & $<0.001$ \\
\hline Cultivar $\times$ time & $<0.001$ & 0.156 \\
\hline
\end{tabular}

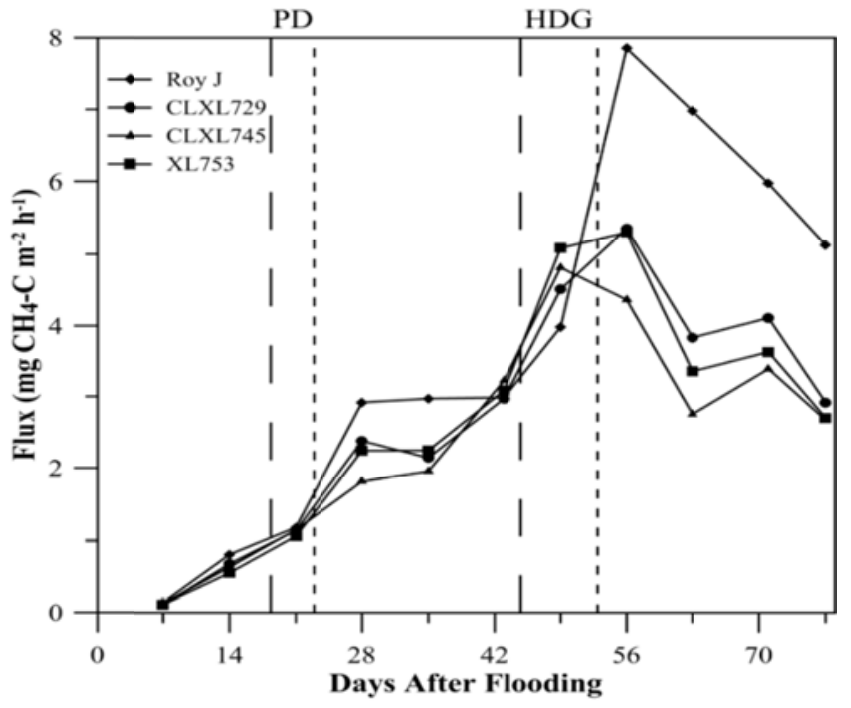

Figure 1. Methane $\left(\mathrm{CH}_{4}\right)$ fluxes measured over time from a pure-line cultivar (Roy J) and three hybrid rice cultivars (CLXL729, CLXL745, and XL753) throughout flooded portion of the 2014 growing season at the Rice Research and Extension Center near Stuttgart, AR. Vertical lines on the graph indicatie approximate dates of panicle differentiation (PD) and 50\% heading (HDG) for the hybrid cultivars (long-dashed lines) and pure-line cultivar (short-dashed lines). The least significant difference for the same cultivar over time is $0.679 \mathrm{mg} \mathrm{CH}_{4}-\mathrm{C} \mathrm{m}{ }^{-2}$ $\mathrm{h}^{-1}$ and for different cultivars over time is $0.824 \mathrm{mg} \mathrm{CH}_{4}-\mathrm{C} \mathrm{m}^{-2} \mathrm{~h}^{-1}$ prior to flood release.

Methane fluxes measured during the flooded portion of the 2014 growing season differed among cultivars over time $(P<0.001$; Table 2$)$. Methane fluxes did not differ among the four cultivars during the first three weeks after flooding or at 43 days after flooding (DAF), while fluxes were greater from Roy J than from one (CLXL745) and two (CLXL745 and CLXL729) of the hybrid cultivars at 28 and 35 DAF, respectively (Figure 1). The pure-line cultivar, Roy J, however, had greater $\mathrm{CH}_{4}$ fluxes than all three hybrid cultivars during the four weeks following $50 \%$ heading. Differences in $\mathrm{CH}_{4}$ fluxes among the three hybrid cultivars were minor with differences occurring at 56 DAF, where fluxes were less from CLXL745 than from the other two hybrids, which did not differ, and at $63 \mathrm{DAF}$, where fluxes were less from 
CLXL745 than from CLXL729, in which both did not differ from XL753 (Figure 1). While the magnitude of fluxes were greater from the pure-line cultivar late in the growing season, all four cultivars exhibited the same general trend where fluxes were all less than $0.14 \mathrm{mg} \mathrm{CH}_{4}-\mathrm{C} \mathrm{m}^{-2} \mathrm{~h}^{-1}$ at $7 \mathrm{DAF}$, then generally increased over time, peaking shortly after $50 \%$ heading at $7.9 \mathrm{mg} \mathrm{CH} \mathrm{CH} \mathrm{m}^{-2} \mathrm{~h}^{-1}$ for Roy $\mathrm{J}$ and 5.3, 5.2, and $4.8 \mathrm{mg} \mathrm{CH}_{4}-\mathrm{C} \mathrm{m}^{-2} \mathrm{~h}^{-1}$ for CLXL729, XL753, and CLXL745, respectively, which did not differ (Figure 1). Fluxes then generally declined for the remainder of the flooded portion of the growing season.

Reduced $\mathrm{CH}_{4}$ fluxes from hybrid cultivars relative to pure-line cultivars have been similarly observed on silt-loam and clay soils by Rogers et al. [30] and Smartt et al. [32], respectively, where fluxes from CLXL745 were significantly less than from two pure-line cultivars (Cheniere and Taggart), especially late in the growing season. Similarly, Simmonds et al. [31] observed a reduction in $\mathrm{CH}_{4}$ emissions from the hybrid CLXL745 relative to the pure-line cultivar, Francis, following heading, while no differences in emissions were observed prior to heading. Although examining cultivars not typically grown in the US, in China, Ma et al. [29] observed reduced dissolved $\mathrm{CH}_{4}$ concentrations in the rhizosphere of hybrid rice as well as a $67 \%$ increase in $\mathrm{CH}_{4}$ oxidation potential relative to pure-line cultivars, while no differences in $\mathrm{CH}_{4}$ production potential were observed. This indicates a potential for increased $\mathrm{CH}_{4}$ oxidation with hybrid cultivars, possibly due to greater methanotrophic activity in the rhizosphere of hybrid rice relative to pure-line cultivars. Butterbach-Bahl et al. [23] attributed a difference in $\mathrm{CH}_{4}$ fluxes among cultivars to differences in $\mathrm{CH}_{4}$ transport capacity, as no differences were measured between potential $\mathrm{CH}_{4}$ productions or oxidations among the cultivars. While several studies suggested differences in gas transport capacity or microbial community structure are the major influencing factors on differences in $\mathrm{CH}_{4}$ fluxes among cultivars, additional studies have consistently suggested that differences in root exudation rates among cultivars are the primary factors that influence differences in $\mathrm{CH}_{4}$ fluxes among cultivars [26, 27, 28, 57, 58].

The seasonal pattern of $\mathrm{CH}_{4}$ emissions increasing once the flood is applied, peaking near heading, then declining prior to flood release has been observed in numerous previous studies $[30,32,49,51,53,59,60$, $61,62]$ and suggests that root exudates increase during vegetative growth providing substrate for methanogenesis and decrease again during grain fill as resources are translocated to the filling grains. Research conducted by Denier van der Gon et al. [63] indicated that $\mathrm{CH}_{4}$ emissions are related to allocation of photosynthetically derived $\mathrm{C}$ between roots and grains and that decreasing translocation of $\mathrm{C}$ to grains (i.e., removing florets prior to grain fill) causes an increase in $\mathrm{C}$ translocation to roots and an increase in $\mathrm{CH}_{4}$ emissions. Sass and Cicerone [64] also determined a link between grain filling and methanogenesis, where increasing $\mathrm{CH}_{4}$ emissions occur as conditions become more unfavorable for spikelet formation, thus decreasing the grain-sink for photosynthates. The plant-related peak in $\mathrm{CH}_{4}$ fluxes observed in this study is common, where additional $\mathrm{C}$ sources, such as rice residue or green manure, have not been introduced to the system and similar seasonal trends have been observed in root growth [65, 66, 67], root exudation rates [28], and anaerobic root respiration rates [68]. Using ${ }^{13} \mathrm{C}$ labeling techniques, Watanabe et al. [69] determined that, when no rice straw was incorporated into the system, 80 to $85 \%$ of $\mathrm{CH}_{4}$ emissions were derived from growing rice plants, while the remainder originated from soil organic matter. Due to low organic residue inputs in this study and based on results of previous research, it would seem that seasonal trends in $\mathrm{CH}_{4}$ fluxes observed in this study are largely linked to plant activity and that reduced fluxes from hybrid cultivars may be a result of reduced root exudation rates relative to the pure-line cultivar.

\subsection{Methane Fluxes Following Flood Release}

Methane fluxes following flood release, which occurred at 78 DAF, differed among cultivars $(P=0.042)$ and over time $(P<0.001$; Table 2$)$. Averaged across time, Roy $\mathrm{J}\left(4.23 \mathrm{mg} \mathrm{CH}_{4} \mathrm{C} \mathrm{m}^{-2} \mathrm{~h}^{-1}\right)$ had greater post-flood-release fluxes than CLXL745 and XL753, which did not differ and averaged $2.95 \mathrm{mg} \mathrm{CH}_{4}-\mathrm{C}$ $\mathrm{m}^{-2} \mathrm{~h}^{-1}$, while CLXL729 (3.56 $\left.\mathrm{mg} \mathrm{CH}_{4}-\mathrm{C} \mathrm{m}^{-2} \mathrm{~h}^{-1}\right)$ did not differ from any of the other cultivars. While post-flood-release fluxes did not differ between Roy J and CLXL 729, the increased fluxes observed in Roy J relative to the other hybrid cultivars are consistent with $\mathrm{CH}_{4}$ fluxes prior to flood release, where fluxes from Roy J were nearly twice as large as from the hybrid cultivars 1 day prior to flood release.

Averaged across cultivar, the measured post-flood-release $\mathrm{CH}_{4}$ flux was greatest 4 days after flood

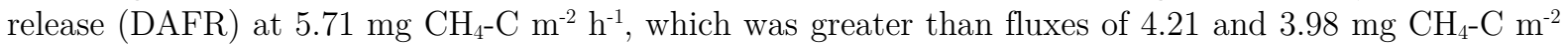


$\mathrm{h}^{-1}$, which did not differ and occurred at 2 and 5 DAFR, respectively. Fluxes incrementally decreased again at 6 and 7 DAFR (2.65 and $0.56 \mathrm{mg} \mathrm{CH}_{4^{-}} \mathrm{C} \mathrm{m}^{-2} \mathrm{~h}^{-1}$, respectively). The post-flood-release pulse of $\mathrm{CH}_{4}$ that occurred in this study has been observed in previous studies $[30,32,48,49,53,54,55,56]$, usually occurring from 3 to 6 DAFR, and is generally attributed to the release of $\mathrm{CH}_{4}$ from soil pores as they drain and allow transport of previously entrapped gases.

\subsection{Aboveground Dry Matter and Grain Yield}

Aboveground dry matter measured at physiological maturity differed among cultivars $(P=0.039)$ and between sampling locations $(P=0.025)$. Averaged across sampling location, aboveground dry matter was greater from XL753 (2862 $\mathrm{g} \mathrm{m}^{-2}$ ) than from CLXL729 and Roy J, which did not differ and averaged $2488 \mathrm{~g} \mathrm{~m}^{-2}$, while aboveground dry matter measured from CLXL745 (2649 $\left.\mathrm{g} \mathrm{m}^{-2}\right)$ did not differ from any of the other cultivars. Although previous studies have observed a positive correlation between $\mathrm{CH}_{4}$ emissions and aboveground dry matter [52, 62, 70, 71], data from this study did not support that relationship, where in this case the cultivar exhibiting greater $\mathrm{CH}_{4}$ fluxes (Roy J) was one of the lowest accumulators of aboveground dry matter. Huang et al. [71] suggested that the relationship between biomass accumulation and $\mathrm{CH}_{4}$ emissions, although correlated when examining the relationship for a single cultivar, was not strong when evaluating the relationship among different cultivars.

Averaged across cultivar, aboveground dry matter was slightly greater inside the chamber $\left(2733 \mathrm{~g} \mathrm{~m} \mathrm{~m}^{-2}\right)$ than outside the chamber in the bulk plot $\left(2510 \mathrm{~g} \mathrm{~m}^{-2}\right)$. Similar studies that examined the effect of sampling location, however, did not observe a significant difference in aboveground dry matter [30, 32, 48, 53]. The difference observed in this study may simply be a factor of chamber placement, where greater plant densities were inadvertently included within the chambers. While the reason for increased biomass accumulation within chambers, which was consistent among cultivars, was not apparent, it would seem that the chambers did not adversely impact plant growth, and, if it did impact $\mathrm{CH}_{4}$ fluxes, the result would be a possible approximate $9 \%$ overestimation of $\mathrm{CH}_{4}$ emissions relative to in-plot plant density.

Similar to aboveground dry matter accumulation and as expected, grain yield differed among cultivars $(P<0.001)$. The hybrid cultivar XL753 achieved the greatest grain yield of $12.3 \mathrm{Mg} \mathrm{ha}^{-1}$, while grain yields from the three other cultivars (CLXL745, CLXL729, and Roy J) did not differ and averaged 9.6 $\mathrm{Mg} \mathrm{ha}^{-1}$. Grain yields measured in this study were similar to those reported by Rogers et al. [30] in a similar study on a silt-loam soil in Arkansas and to results of Arkansas Rice Performance Trials conducted in 2014, where XL753, CLXL745, CLXL729, and Roy J attained grain yields of 12.7, 10.0, 9.9, and $9.9 \mathrm{Mg} \mathrm{ha}^{-1}$, respectively [38].

\subsection{Seasonal Methane Emissions}

As expected, based on $\mathrm{CH}_{4}$ flux measurements throughout the growing season, season-long, area-scaled $\mathrm{CH}_{4}$ emissions differed among cultivars $(P=0.001)$, where emissions were greater from Roy $\mathrm{J}(74.8 \mathrm{~kg}$

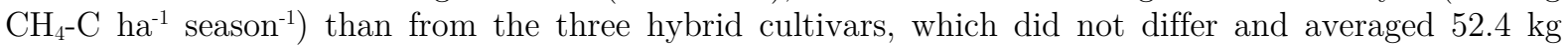
$\mathrm{CH}_{4}-\mathrm{C}$ ha ${ }^{-1}$ season $^{-1}$ (Table 3). The $30 \%$ reduction in $\mathrm{CH}_{4}$ emissions from hybrid rice cultivars relative to a pure-line cultivar in this study is consistent with previous studies where Smartt et al. [32] and Rogers et al. [30] observed reductions of 31 and 37\%, respectively, from CLXL745 relative to two pure-line cultivars on a clay and silt-loam soil, respectively. Similarly, Simmonds et al. [31] measured a $25 \%$ reduction from CLXL745 relative to pure-line cultivars in Arkansas, while no differences in $\mathrm{CH}_{4}$ emissions between hybrid and pure-line cultivars were detected in California. The magnitude of $\mathrm{CH}_{4}$ emissions measured in this study were 56 to $60 \%$ less than emissions measured from similar treatments by Rogers et al. [30] on a similar soil. Lower emissions measured in this study relative to those reported by Rogers et al. [30] may be due to a combination of lower sand content or greater extractable soil P, both of which have been shown to result in reduced emissions [72, 73]. Results obtained by AdvientoBorbe et al. [54], where emissions from CLXL745 averaged $44 \mathrm{~kg} \mathrm{CH}_{4}-\mathrm{C} \mathrm{ha}^{-1}$ season $^{-1}$, and Simmonds et al. [31], where emissions from CLXL745 were $56 \mathrm{~kg} \mathrm{CH}_{4}-\mathrm{C}$ ha $^{-1}$ season $^{-1}$ and three pure-line cultivars averaged $75 \mathrm{~kg} \mathrm{CH}_{4}-\mathrm{C}$ ha $^{-1}$ season $^{-1}$, however, were consistent with the results of this study. 
Table 3. Summary of methane (CH4) emissions as affected by cultivar expressed on season-long, area- and yieldscaled bases, post-flood release area-scaled basis, and post-flood release percentage of total seasonal emissions from a silt-loam soil during the 2014 growing season at the Rice Research and Extension Center near Stuttgart, AR.

\begin{tabular}{|c|c|c|c|c|c|}
\hline \multirow{2}{*}{ Emissions property } & \multicolumn{4}{|c|}{ Cultivar } & \multirow[b]{2}{*}{$P$} \\
\hline & CLXL729 & CLXL745 & XL753 & Roy J & \\
\hline Area-scaled emissions $\left(\mathrm{kg} \mathrm{CH}_{4}-\mathrm{C}\right.$ ha $^{-1}$ season $\left.^{-1}\right)$ & $55.3 \mathrm{~b}^{\dagger}$ & $48.9 \mathrm{~b}$ & $53.0 \mathrm{~b}$ & $74.8 \mathrm{a}$ & 0.001 \\
\hline Yield-scaled emissions $\left[\mathrm{kg} \mathrm{CH}_{4}-\mathrm{C}(\mathrm{Mg} \text { grain })^{-1}\right]$ & $5.85 \mathrm{~b}$ & $5.08 \mathrm{bc}$ & $4.31 \mathrm{c}$ & $7.85 \mathrm{a}$ & $<0.001$ \\
\hline Post-flood emissions $\left(\mathrm{kg} \mathrm{CH}_{4}-\mathrm{C} \mathrm{ha}^{-1}\right)$ & $6.21 \mathrm{~b}$ & $5.30 \mathrm{~b}$ & $5.18 \mathrm{~b}$ & $8.26 \mathrm{a}$ & 0.010 \\
\hline Post-flood emissions (\% total emissions) & 11.2 & 10.8 & 9.8 & 11.1 & 0.612 \\
\hline
\end{tabular}

${ }^{\dagger}$ Values in the same row followed by different letters are significantly different $(P<0.05)$.

Similar to area-scaled emissions, yield-scaled $\mathrm{CH}_{4}$ emissions differed among cultivars $(P<0.001$; Table 3). Yield-scaled emissions from Roy J were greatest at $7.85 \mathrm{~kg} \mathrm{CH}_{4} \mathrm{C}(\mathrm{Mg} \text { grain })^{-1}$. As a result of a greater grain yield, XL753 (4.31 $\left.\mathrm{kg} \mathrm{CH}_{4} \mathrm{C}(\mathrm{Mg} \text { grain })^{-1}\right)$ resulted in lower yield-scaled emissions than CLXL729 (5.85 $\mathrm{kg} \mathrm{CH}_{4} \mathrm{C}$ ( $\mathrm{Mg}$ grain) $)^{-1}$ ), while yield-scaled emissions from CLXL745 did not differ from that from either of the other hybrid cultivars (Table 3). Although grain yields were similar between the two studies, yield-scaled emissions from this study were much less than emissions of 11.1 and $20.1 \mathrm{~kg}$ $\mathrm{CH}_{4}-\mathrm{C}$ (Mg grain) ${ }^{-1}$ from CLXL745 and two pure-line cultivars, respectively, reported by Rogers et al. [30] due to differences in area-scaled $\mathrm{CH}_{4}$ emissions. Yield-scaled emissions in this study were reduced by 25, 35, and 45\% from CLXL729, CLXL745, and XL753, respectively, relative to Roy J. Smartt et al. [32] measured a similar reduction in yield-scaled $\mathrm{CH}_{4}$ emissions of 37\% from CLXL745 relative to two pureline cultivars. Rogers et al. [30] observed a reduction in yield-scaled emissions of $45 \%$ from CLXL745 relative to two hybrids, which is slightly greater than the reduction from CLXL745 observed here due to a $12 \%$ increase in grain yield from the hybrid relative to the two pure-line cultivars, while yields from CLXL745 and Roy J did not differ in this study.

Methane emissions following flood release differed among cultivars on an area-scaled basis $(P=0.010)$, while no differences were observed when $\mathrm{CH}_{4}$ emissions were expressed as a percentage of total seasonal emissions $(P=0.612)$ (Table 3). Similar to results of $\mathrm{CH}_{4}$ fluxes and total emissions, post-flood-release emissions were greater from Roy J $\left(8.26 \mathrm{~kg} \mathrm{CH}_{4}-\mathrm{C} \mathrm{ha}^{-1}\right)$ than from the three hybrid cultivars, which did not differ and averaged $5.56 \mathrm{~kg} \mathrm{CH}_{4}-\mathrm{C}$ ha $^{-1}$ (Table 3). As a percentage of total area-scaled $\mathrm{CH}_{4}$ emissions, however, post-flood-release emissions did not differ among cultivars and averaged 10.7\%. Rogers et al. [30] measured post-flood release emissions ranging from 6.8 to $27.4 \mathrm{~kg} \mathrm{CH}_{4}-\mathrm{C}$ ha-1, which were generally greater than those reported here, likely due to greater overall seasonal emissions. The proportion of $\mathrm{CH}_{4}$ emitted following flood release in this study, however, was similar to emissions ranging from $10.5 \%$ from CLXL745 to $16 \%$ from a semi-dwarf, pure-line cultivar observed by Rogers et al. [30]. Post-flood $\mathrm{CH}_{4}$ release has been observed in numerous previous studies ranging from 3 to $20 \%$ of total area-scaled emissions $[30,32,51,54,56,70,74]$. While the magnitude of post-flood-release $\mathrm{CH}_{4}$ emissions differs among various treatments, it has become apparent that $\mathrm{CH}_{4}$ has the potential to accumulate in saturated soils and be released as the soil dries and macropores become accessible for gas transport.

\section{Conclusions}

Numerous studies have provided evidence of differences in microbial community structure, $\mathrm{CH}_{4}$ production and oxidation rates, gas transport capacities, and root exudation rates that result in differential $\mathrm{CH}_{4}$ emissions among rice cultivars. The impact of these various factors has not been well studied in US rice production, but evidence has consistently demonstrated a reduction in $\mathrm{CH}_{4}$ emissions from hybrid rice cultivars grown in the US. This study has elaborated on previous works and demonstrated that other hybrid cultivars have a similar capacity to reduce $\mathrm{CH}_{4}$ emissions relative to pure-line cultivars as CLXL745, which has been consistently demonstrated in the mid-southern US. Studies have regularly reported a link between photosynthetically derived $\mathrm{C}$ and $\mathrm{CH}_{4}$ emissions, indicating that differences in $\mathrm{C}$ partitioning and root exudation among cultivars can greatly impact $\mathrm{CH}_{4}$ emissions. Plant-derived $\mathrm{C}$ plays a major role in $\mathrm{CH}_{4}$ emissions from rice, particularly where organic 
residue inputs into the system are limited, such as in the mid-southern US, where rice is generally rotated with soybean and crop residues are largely decomposed prior to flooding the subsequent rice crop. The mitigation of $\mathrm{CH}_{4}$ emissions by hybrid rice cultivars demonstrated in this study shows that simple changes like growing high-yielding, low-emitting cultivars, such as the hybrids included in this study, have great potential for reducing $\mathrm{CH}_{4}$ emissions from rice produced in the US. While other mitigation strategies may be difficult to implement, expensive, and cause yield reductions, switching to cultivars such as XL753 shows potential to decrease $\mathrm{CH}_{4}$ emissions, while maintaining or even increasing yields.

Acknowledgements. The authors would like to acknowledge the Arkansas Rice Research and Promotion Board for funding this research. Additional appreciation goes to Will Smartt, Jarrod Hardke, Donna Frizzell, Eduardo Castaneda-Gonzalez, and Chuck Pipkins for assistance they provided to this research.

\section{References}

1. P. Baicich, "The birds and rice connection. Bird watcher's digest," Available: http://www.greatbirdingprojects. com/images/BWD_J-A_13_BIRDS_N_RICE.pdf

2. P. Forster, V. Ramaswamy, P. Artaxo, T. Berntsen, R. Betts, D.W. Fahey, et al., "Changes in atmospheric constituents and in radiative forcing," in: S. Solomon, D. Qin, M. Manning, Z. Chen, M. Marquis, K.B. Averyt, M.Tignor, and H.L. Miller, editors, Climate change 2007: The physical science basis. Contribution of working group I to the Fourth Assessment Report of the Intergovernmental Panel on Climate Change. Cambridge University Press, 2007.

3. B.A. Linquist, K.J. van Groenigen, M.A. Adviento-Borbe, C. Pittelkow, and C. van Kessel, "An agronomic assessment of greenhouse gas emissions from major cereal crops," Global Change Biol., vol. 18, pp. 194-209, 2011.

4. B.A. Linquist, M.A. Adviento-Borbe, C.M. Pittelkow, C. van Kessel, and K. van Groenigen, "Fertilizer management practices and greenhouse gas emissions from rice systems: A quantitative review and analysis," Field Crop Res., vol. 135, pp. 10-21, 2012.

5. I. Karakurt, G. Aydin, and K. Aydiner, "Sources and mitigation of methane emissions by sectors: a critical review," Renew. Energy, vol. 39, pp. 40-48, 2012.

6. P. Smith, D. Martino, Z. Cai, D. Gwary, H. Janzen, P. Kumar, et al., "Agriculture," in: S. Solomon, D. Qin, M. Manning, Z. Chen, M. Marquis, K.B. Averyt, M.Tignor and H.L. Miller, editors, Climate change 2007: The physical science basis. Contribution of working group I to the Fourth Assessment Report of the Intergovernmental Panel on Climate Change. Cambridge University Press, 2007.

7. United States Environmental Protection Agency (USEPA), "Global anthropogenic non-CO2 greenhouse gas emissions: 1990 - 2020," Available: http://nepis.epa.gov/Adobe/PDF/ 2000ZL5G.pdf

8. United States Environmental Protection Agency (USEPA), "Inventory of U.S. greenhouse gas emissions and sinks: 1990-2014," Available: https://www.epa.gov/sites/production/files/2016-04/documents/us-ghg-inventory2016-main-text.pdf

9. L. Nazaries, J.C. Murrell, P. Millard, L. Baggs, and B.K. Singh, "Methane, microbes and models: Fundamental understanding of the soil methane cycle for future predictions," Environ. Microbiol., vol. 15, pp. 2395-2417, 2013.

10.N. Serrano-Silva, Y. Sarria-Guzman, L. Dendooven, and M. Luna-Guido, "Methanogenesis and methanotrophy in soil: a review," Pedosphere, vol. 24, no. 3, pp. 291-307, 2014.

11.R. Grosskopf, S. Stubner, and W. Liesack, "Novel euryarchaeotal lineages detected on rice roots and in the anoxic bulk soil of flooded rice mesocosms," Appl. Environ. Microbiol., vol. 64, pp. 4983-4989, 1998.

12.M. Kruger, G. Eller, R. Conrad, and P. Frenzel, "Seasonal variation in pathways of CH4 production and in CH4 oxidation in rice fields determined by stable carbon isotopes and specific inhibitors," Glob. Change Biol., vol. 8, pp. 265-280, 2002.

13.R. Conrad, C. Erkel, and W. Liesack, "Rice cluster I methanogens, an important group of Archaea producing greenhouse gas in soil," Curr. Opin. Biotech., vol. 17, pp. 262-267, 2006.

14.Y.H. Lu, and R. Conrad, "In situ stable isotope probing of methanogenic archaea in the rice rhizosphere," Science, vol. 309, pp. 1088-1090, 2005. 
15.A. Holzapfel-Pschorn, R. Conrad, and W. Seiler, "Production, oxidation, and emissions of methane in rice paddies," FEMS Microbiol. Ecol., vol. 31, pp. 343-351, 1985.

16.A. Holzapfel-Pschorn, R. Conrad, and W. Seiler, "Effects of vegetation on the emission of methane from submerged paddy soil," Plant Soil, vol. 92, pp. 223-233, 1986.

17.R.L. Sass, F.M. Fisher, P.A. Harcombe, and F.T. Turner, "Methane production and emissions in a Texas rice field," Global Biogeochem. Cy., vol. 4, pp. 47-68, 1990.

18.R.L. Sass, F.M. Fisher, Y.B. Wang, F.T. Turner, and M.F. Jund, "Methane emissions from rice fields: The effect of flood water management," Global Biogeochem. Cy., vol. 6, pp. 249-262, 1992.

19.H. Schutz, A. Holzapfel-Pschorn, R. Conrad, H. Rennenberg, and W. Seiler, "A 3-year continuous record on the influence of daytime, season, and fertilizer treatment on methane emission rates from in Italian rice paddy,' J. Geophys. Res., vol. 94, no. D13, pp. 16405-16416, 1989.

20.W. Armstrong, "Radial oxygen losses from intact rice: an analysis of intervarietal differences in oxygen flux from the roots," Physiol. Plantarum., vol. 25, pp. 192-197, 1971.

21.R. Conrad and F. Rothfuss, "Methane oxidation in the soil surface layer of a flooded rice field and the effect of ammonium," Biol. Fert. Soils, vol. 12, pp. 28-32, 1991.

22.F. Rothfuss and R. Conrad, "Effect of gas bubbles on the diffusive flux of methane in anoxic paddy soil," Limnol. Oceanogr., vol. 43, pp. 1511-1518, 1998.

23.K. Butterbach-Bahl, H. Papen, and H. Rennenberg, "Impact of gas transport through rice cultivars on methane emission from rice paddy fields," Plant Cell Environ., vol. 20, pp. 1175-1183, 1997.

24.I. Nouchi, S. Mariko, and K. Aoki, "Mechanism of methane transport from the rhizosphere to the atmosphere through rice plants," Plant Physiol., vol. 94, pp. 59-66, 1990.

25.R.L. Sass and F.M. Fisher, "Methane emissions from rice paddies: a process study summary," Nutr. Cycl. Agroecosys., vol. 49, pp. 119-127, 1997.

26.L.K. Sigren, G.T. Byrd, F.M. Fisher, and R.L. Sass, "Comparison of soil acetate concentrations and methane production, transport, and emission in two rice cultivars," Global Biogeochem. Cy., vol. 11, pp. 1-14, 1997.

27.H.U. Neue, R.Wassmann, H.K. Kludze, W. Bujun, and R.S. Lantin, "Factors and processes controlling methane emissions from rice fields," Nutr. Cycl. Agroecosys., vol. 49, pp. 111-117, 1997.

28.M.S. Aulakh, R. Wassmann, C. Bueno, J. Kreuzwieser, and H. Rennenberg, "Characterization of root exudates at different growth stages of ten rice (Oryza sativa L.) cultivars," Plant Biol., vol. 3, pp. 139-148, 2001.

29.K. Ma, Q. Qiu, and Y. Lu, "Microbial mechanism for rice variety control on methane emission from rice field soil," Global Change Biol., vol. 16, pp. 3085-3095, 2010.

30.C.W. Rogers, K.R. Brye, A.D. Smartt, R.J. Norman, E.E. Gbur, and M.A. Evans-White, "Cultivar and previous crop effects on methane emissions from drill-seeded, delayed-flood rice production on a silt-loam soil," Soil Sci., vol. 179, pp. 28-36, 2014.

31.M.B. Simmonds, M. Anders, M.A. Adviento-Borbe, C. van Kessel, A. McClung, and B.A. Linquist, "Seasonal methane and nitrous oxide emissions of several rice cultivars in direct-seeded systems," J. Environ. Qual., vol. 44, pp. 103-114, 2015.

32.A.D. Smartt, K.R. Brye, C.W. Rogers, R.J. Norman, E.E. Gbur, J.T. Hardke, and T.L. Roberts, "Previous crop and cultivar effects on methane emissions from drill-seeded, delayed-flood rice grown on a clay soil," Applied and Environmental Soil Science, vol. 2016, Article ID 9542361, 2016.

33.J.T. Hardke, "Trends in Arkansas rice production, 2015," in: R.J. Norman and K.A.K Moldenhauer, editors, B.R. Wells rice research studies, 2015, Arkansas AES Res. Ser. 634, pp. 13-23, 2016.

34.Soil Survey Staff, Natural Resources Conservation Service (NRCS), United States Department of Agriculture (USDA), Web Soil Survey, Available: http://websoilsurvey.sc.egov.usda.gov/App/ HomePage.htm

35.Natural Resources Conservation Service (NRCS) and United States Department of Agriculture (USDA), Land resource regions and major land resource areas of the United States, the Caribbean, and the Pacific Basin, Available: https://www.nrcs.usda.gov/Internet/FSE_DOCUMENTS/nrcs142p2_050898.pdf

36.J.T. Hardke, "Reviewing the 2016 Arkansas Rice Season," Available: http://www.uaex.edu/ farm-ranch/ cropscommercial-horticulture/rice/Reviewing\%20the\%202016\%20Arkansas\%20Rice\%20Season.pdf

37.K.A.K. Moldenhauer, J.W. Gibbons, F.N. Lee, J.L. Bernhardt, C.E. Wilson, R. Cartwright, et al., "'Roy J', high yielding, stiff-strawed, long-grain rice variety," in: R.J. Norman and K.A.K Moldenhauer, editors, B.R. Wells rice research studies, 2009, Arkansas AES Res. Ser. 581, pp. 53-59, 2010. 
38.J.T. Hardke, D.L. Frizzell, E. Castaneda-Gonzalez, G.J. Lee, K.A.K. Moldenhauer, X. Sha, "Arkansas rice performance trials, 2013-2015," in: R.J. Norman and K.A.K Moldenhauer, editors, B.R. Wells rice research studies, 2015, Arkansas AES Res. Ser. 634, pp. 267-274, 2016.

39.J.T. Hardke, editor, Arkansas rice production handbook, University of Arkansas Division of Agriculture Cooperative Extension Service MP192, Little Rock, AR., 2013.

40.R. Norman, N. Slaton, and T. Roberts. "Soil Fertility," in: J.T. Hardke, editor, Arkansas rice production handbook, University of Arkansas Division of Agriculture Cooperative Extension Service MP192, Little Rock, AR., pp. 69-102, 2013.

41.G. Lorenz and J.T. Hardke, "Insect management in rice," in: J.T. Hardke, editor, Arkansas rice production handbook, University of Arkansas Division of Agriculture Cooperative Extension Service MP192, Little Rock, AR., pp. 139-162, 2013.

42.B. Scott, J. Norsworthy, T. Barber, and J. Hardke, "Rice weed control," in: J.T. Hardke, editor, Arkansas rice production handbook, University of Arkansas Division of Agriculture Cooperative Extension Service MP192, Little Rock, AR., pp. 53-62, 2013.

43.M.R. Tucker, "Determination of phosphorus by Mehlich 3 extraction," in: S.J. Donohue, editor, Soil and media diagnostic procedures for the Southern Region of the United States, VA. Agr. Exp. Stat. B. 374 . Virginia Agricultural Experiment Station, Blacksburg, VA., pp. 6-8, 1992.

44.D.W. Nelson and L.E. Sommers, "Total carbon, organic carbon, and organic matter," in: D.L. Sparks, A.L. Page, P.A. Helmke, R.H. Loeppert, P.N. Soltanpour, M.A. Tabatabai, C.T. Johnston, and M.E. Sumner, editors, Methods of soil analysis. Part 3: Chemical analysis, 3rd ed. SSSA, Madison, WI., pp. 961-1010, 1996.

45.E.E. Schulte and B.G. Hopkins, "Estimation of organic matter by weight loss-on-ignition," in: F.R. Magdoff, M.A. Tabatabai, and E.A. Hanlon Jr., editors, Soil Science Society of America Special, Madison, WI., pp. 21-31, 1996.

46.G.W. Gee and D. Or, "Particle-size analysis," in: J.H. Dane and G.C. Topp, editors, Methods of soil analysis. Part 4: Physical methods, 1st ed. SSSA, Madison, WI. pp. 255-293, 2002.

47.G. Livingston and G. Hutchinson. "Enclosure-based measurement of trace gas exchange: applications and sources of error," in: P.A. Matson and R.C. Harriss, editors, Biogenic Trace Gases: Measuring Emissions from Soil and Water, Blackwell Sciences Ltd., Osney Mead, Oxford, pp. 14-51, 1995.

48.K.R. Brye, C.W. Rogers, A.D. Smartt, and R.J. Norman, "Soil texture effects on methane emissions from directseeded, delayed-flood rice production in Arkansas," Soil Sci., vol. 178, pp. 519-529, 2013.

49.A.D. Smartt, K.R. Brye, C.W. Rogers, R.J. Norman, E.E. Gbur, J.T. Hardke, and T.L. Roberts, "Characterization of methane emissions from rice production on a clay soil in Arkansas," Soil Sci., vol. 181, pp. 57-67, 2016.

50.T. Parkin and R. Venterea. "Chamber-based trace gas flux measurements," in: R. Follett, editor, Sampling protocols, Available: www.ars.usda.gov/research/GRACEnet

51.C.W. Rogers, K.R. Brye, R.J. Norman, E.E. Gbur, J.D. Mattice, T.B. Parkin, and T.L. Roberts, "Methane emissions from drill-seeded, delayed-flood rice production on a silt-loam soil in Arkansas," J. Environ. Qual., vol. 42, pp. 1059-1069, 2013.

52.Q. Shang, X. Yang, C. Gao, P. Wu, J. Liu, Y. Xu, Q. Shen, J. Zou, and S. Guo, "Net annual global warming potential and greenhouse gas intensity in Chinese double rice-cropping systems: a 3-year field measurement in long-term fertilizer experiments," Glob. Change Biol. vol. 17, pp. 2196-2210, 2011.

53.A.D. Smartt, K.R. Brye, C.W. Rogers, R.J. Norman, E.E. Gbur, J.T. Hardke, and T.L. Roberts, "Chamber size effects on methane emissions from rice production," Open Journal of Soil Science, vol. 5, pp. 227-235, 2015.

54.M.A. Adviento-Borbe, C.M. Pittelkow, M. Anders, C. van Kessel, J.E. Hill, A.M. McClung, J. Six, and B.A. Linquist, "Optimal fertilizer nitrogen rates and yield-scaled global warming potential in drill seeded rice," J. Environ. Qual. Vol. 42, pp. 1623-1634, 2014.

55.D.A. Bossio, W.R. Horwath, R.G. Mutters, and C. van Kessel, "Methane pool and flux dynamics in a rice field following straw incorporation," Soil Biol. Biochem., vol. 31, pp. 1313-1322, 1999.

56.H.A.C. Denier van der Gon, N. van Breemen, H.U. Neue, R.S. Lantin, J.B. Aduna, M.C.R. Alberto, and R. Wassmann, "Release of entrapped methane from wetland rice fields upon soil drying," Global Biogeochem. Cy., vol. 10, pp. 1-7, 1996. 
57.Y. Lou, K. Inubushi, T. Mizuno, T. Hasegawa, Y. Lin, H. Sakai, W. Cheng, and K. Kobayashi, "CH4 emissions with differences in atmospheric CO2 enrichment and rice cultivars in a Japanese paddy soil," Global Change Biol., vol. 14, pp. 2678-2687, 2008.

58.B. Wang and K. Adachi, "Differences among rice cultivars in root exudation, methane oxidation, and populations of methanogenic and methanotrophic bacteria in relation to methane emissions," Nutr. Cycl. Agroecosys., vol. 58, pp. 349-356, 2000.

59.Y. Huang, Y. Jiao, L. Zong, X. Zheng, R.L. Sass, and F.M. Fisher, "Quantitative dependence of methane emission on soil properties," Nutr. Cycl. Agroecosys., vol. 64, pp. 157-167, 2002.

60.I. Nouchi, T. Hosono, K. Aoki, and K. Minami, "Seasonal variation in methane flux from rice paddies associated with methane concentration in soil water, rice biomass and temperature, and its modeling," Plant Soil, vol. 161, pp. 195-208, 1994.

61.R.L. Sass, F.M. Fisher, P.A. Harcombe, and F.T. Turner, "Mitigation of methane emissions from rice fields: Possible adverse effects of incorporated rice straw," Global Biogeochem. Cy., vol. 5, pp. 275-287, 1991.

62.R.L. Sass, F.M. Fisher, F.T. Turner, and M.F. Jund, "Methane emissions from rice fields as influenced by solar radiation, temperature, and straw incorporation," Global Biogeochem. Cy., vol. 5, pp. 335-350, 1991.

63.H.A.C. Denier van der Gon, M.J. Kropff, N. van Breemen, R. Wassmann, R.S. Lantin, E. Aduna, T.M. Corton, and H.H. van Laar, "Optimizing grain yields reduces CH4 emissions from rice paddy fields," P. Natl. Acad. Sci. USA, vol. 99, pp. 12021-12024, 2002.

64.R.L. Sass and R.J. Cicerone, "Photosynthate allocations in rice plants: food production or atmospheric methane?," P. Natl. Acad. Sci. USA, vol. 99, pp. 11993-11995, 2002.

65.C.A. Beyrouty, B.R. Wells, R.J. Norman, J.N. Marvel, and J.A. Pillow, "Root growth dynamics of a rice cultivar grown at two locations," Agron. J., vol. 80, pp. 1001-1004, 1988.

66.C.A. Beyrouty, R.J. Norman, B.R. Wells, M.G. Hanson, and E.E. Gbur, "Shoot and root growth of eight rice cultivars," in: B.R. Wells, editor, Arkansas rice research studies 1992. Arkansas AES Res. Ser. 431, pp. 119-122, 1993.

67.N.A. Slaton, C.A. Beyrouty, B.R. Wells, R.J. Norman, and E.E. Gbur, "Root growth and distribution of two short-season rice genotypes," Plant Soil, vol. 121, pp. 269-278, 1990.

68.M.D. Tolley, R.D. DeLaune, and W.H. Patrick, "The effect of sediment redox potential and soil acidity on nitrogen uptake, anaerobic root respiration, and growth of rice (Oryza sativa)," Plant Soil, vol. 93, pp. 323-331, 1986.

69.A. Watanabe, T. Takeda, and M. Kimura, "Evaluation of origins of CH4 carbon emitted from rice paddies," J. Geophys. Res., vol. 104(D19), pp. 23623-23629, 1999.

70.R.J. Cicerone, and J.D. Shetter, "Sources of atmospheric methane: Measurements in rice paddies and a discussion," J. Geophys. Res., vol. 86(C8), pp. 7203-7209, 1981.

71.Y. Huang, R.L. Sass, and F.M. Fisher, "Methane emission from Texas rice paddy soils. 2. Seasonal contribution of rice biomass production to CH4 $\neg$ emission," Glob. Change Biol., vol. 3, pp. 491-500, 1997.

72.Y. Lu, R. Wassmann, H.U. Neue, and C. Huang, "Impact of phosphorus supply on root exudation, aerenchyma formation and methane emission of rice plants," Biogeochemistry, vol. 47, pp. 203-218, 1999.

73.R.L. Sass, F.M. Fisher, S.T. Lewis, F.T. Turner, and M.F. Jund, "Methane emission from rice fields: Effects of soil properties," Global Biogeochem. Cy., vol. 8, pp. 135-140, 1994.

74.K. Yagi, H. Tsuruta, and K. Minami, "Possible options for mitigating methane emissions from rice cultivation," Nutr. Cycl. Agroecosys. vol. 49, pp. 213-220, 1997. 